ARTICLE

\title{
Fossils from Mille-Logya, Afar, Ethiopia, elucidate the link between Pliocene environmental changes and Homo origins
}

\author{
Zeresenay Alemseged ${ }^{1 凶}$, Jonathan G. Wynn², Denis Geraads ${ }^{3}$, Denne Reed ${ }^{4}$, W. Andrew Barr ${ }^{5}$, \\ René Bobe (1) 6,7,8, Shannon P. McPherron ${ }^{9}$, Alan Deino ${ }^{10}$, Mulugeta Alene ${ }^{11}$, Mark J. Sier (1) 12,13, \\ Diana Roman ${ }^{14} \&$ Joseph Mohan ${ }^{15}$
}

Several hypotheses posit a link between the origin of Homo and climatic and environmental shifts between 3 and $2.5 \mathrm{Ma}$. Here we report on new results that shed light on the interplay between tectonics, basin migration and faunal change on the one hand and the fate of Australopithecus afarensis and the evolution of Homo on the other. Fieldwork at the new MilleLogya site in the Afar, Ethiopia, dated to between 2.914 and 2.443 Ma, provides geological evidence for the northeast migration of the Hadar Basin, extending the record of this lacustrine basin to Mille-Logya. We have identified three new fossiliferous units, suggesting in situ faunal change within this interval. While the fauna in the older unit is comparable to that at Hadar and Dikika, the younger units contain species that indicate more open conditions along with remains of Homo. This suggests that Homo either emerged from Australopithecus during this interval or dispersed into the region as part of a fauna adapted to more open habitats.

\footnotetext{
${ }^{1}$ Department of Organismal Biology and Anatomy, University of Chicago, Chicago, IL 60637, USA. ${ }^{2}$ Division of Earth Sciences, National Science Foundation, Alexandria, VA, USA. ${ }^{3}$ CR2P, Sorbonne Universités, MNHN, CNRS, UPMC, CP 38, 8 rue Buffon, 75231, PARIS Cedex 05, France. ${ }^{4}$ Department of Anthropology, University of Texas at Austin, Austin, TX 78712, USA. ${ }^{5}$ Center for the Advanced Study of Human Paleobiology. Department of Anthropology, The George Washington University, Washington, DC 20052, USA. ${ }^{6}$ Primate Models for Behavioural Evolution Lab, Institute of Cognitive \& Evolutionary Anthropology, School of Anthropology, University of Oxford, Oxford, UK. ${ }^{7}$ Gorongosa National Park, Sofala, Mozambique. ${ }^{8}$ Interdisciplinary Center for Archaeology and Evolution of Human Behavior (ICArEHB), Universidade do Algarve, Faro, Portugal. ${ }^{9}$ Department of Human Evolution, Max Planck Institute for Evolutionary Anthropology, Leipzig, Germany. ${ }^{10}$ Berkeley Geochronology Center, 2455 Ridge Road, Berkeley, CA, USA. ${ }^{11}$ School of Earth Sciences, Addis Ababa University, P. O. Box 1176Addis Ababa, Ethiopia. ${ }^{12}$ CENIEH, Paseo Sierra de Atapuerca 3, 09002 Burgos, Spain. ${ }^{13}$ Department of Earth Sciences, University of Oxford, South Parks Road, Oxford OX1 3AN, UK. ${ }^{14}$ Earth and Planets Laboratory, Carnegie Institution for Science, Washington, DC 20015-1305, USA. ${ }^{15}$ Climate Change Institute, University of Maine, Orono, ME 04469-5790, USA. ${ }^{\bowtie}$ email: alemseged@uchicago.edu
} 
F or many decades, a disparity between the resolution of long and continuous marine paleoclimate records versus fragmentary and time-averaged terrestrial records has hampered our ability to establish precise links between human evolution and major environmental changes. However, a recent proliferation of fieldwork ${ }^{1-4}$, new drilling campaigns targeting highly detailed and relatively continuous paleolake records $s^{5,6}$, and novel geochemical approaches ${ }^{7-10}$ are helping to assess terrestrial environmental dynamics at finer resolutions. Despite this progress, it remains the case that fauna, particularly hominins, are poorly sampled from the crucial time range between 3 and $2.5 \mathrm{Ma}$ because fossiliferous sediments dating to this interval are rare. Although prolific deposits of the Omo-Turkana Basin in Ethiopia and Kenya do contain sediments from this interval, the hominin fossils are fragmentary and their taxonomic identities are uncertain. Sedimentary basins of the Afar in Ethiopia are highly fossiliferous, containing the most complete hominin record of the past 6 million years, alongside diverse faunas and well-established chronologies, but the 3-2.5 Ma interval is very poorly represented ${ }^{11}$.

The Mille-Logya Project (MLP) is a new paleoanthropological site, dated from ca. 2.9 to $2.4 \mathrm{Ma}$, at the northeast end of the wellknown Plio-Pleistocene sites in the Awash Valley of the Afar Regional State, Ethiopia (Fig. 1). Research at Mille-Logya started in 2012 and our team conducted systematic geological and paleontological surveys in 2014, 2015, 2016, 2018, and 2019. Here, we provide the first report on the geological and paleontological content of this site.

The fossiliferous sediments exposed at Mille-Logya are generally younger than most of other known research areas in the region. Thus, they offer a unique opportunity to elucidate major events in human evolution including the transition from Australopithecus to Homo, the emergence of Paranthropus, and the advent of manufactured stone tools ${ }^{12,13}$. Furthermore, although Australopithecus afarensis is the most abundantly preserved hominin from the region between 3.8 and $2.9 \mathrm{Ma}$, its fate is largely unknown because of a regional hiatus in the sedimentary record of the Hadar Basin between 2.9 and $2.7 \mathrm{Ma}^{14}$. Above this unconformity, the sediments of the Busidima Formation fill a local half graben near the western escarpment of the Ethiopian Rift $^{15}$. Compared to the largely lacustrine and peri-lacustrine Hadar Formation, the Busidima Formation exhibits a very different style of deposition, characterized by low sedimentation rates in almost exclusively episodic, high-energy fluvial settings, resulting in relatively poor fossil preservation. Meanwhile, during this same interval (2.9-2.7 Ma), lacustrine and peri-lacustrine sediments were deposited at Mille-Logya and continue into younger horizons.

Our geological work offers new evidence for the northeast migration of the Hadar Basin, expanding our knowledge of the history of the basin substantially. Three new fossiliferous horizons with differing faunal composition have been identified suggesting in situ faunal change. While the fauna in the older unit is comparable to that at Hadar and Dikika, the younger units contain species that indicate more open conditions along with remains of Homo. New data from Mille-Logya reveal how hominins and other fauna responded to environmental changes during this key period. Our results show a connection between geotectonics, sedimentary basin migration and an in situ faunal change. We also provide new evidence that could potentially explain what happened to Australopithecus afarensis after $2.9 \mathrm{Ma}$ and what caused the dispersal to or the emergence of Homo in the region.

\section{Results}

Geology. Stratigraphic surveys of the Mille-Logya area were geared toward broadening our understanding of the geological history of the region. To achieve this, it is crucial not only to establish chronological relationships between fossiliferous sites, but to investigate stratigraphic, structural and facies relationships between discontinuous exposures of sedimentary basins ${ }^{16,17}$. Early geological maps of the region showed isolated PlioPleistocene sediments within the new site, amidst basalt flows attributed to the Afar Stratoid Series ${ }^{18,19}$. In these broad-scale maps, the sediments were attributed to undifferentiated Quaternary strata or the White Series (Enkafala Beds; both mapping units, were also used to indicate outcrops of the Hadar Formation $^{20-22}$, the latter having been much more thoroughly scrutinized since initial fossil discoveries at the Hadar site ${ }^{23-30}$ ). Sediments in areas nearby ${ }^{11,31,32}$ broadly bracket and partly overlap with the strata of the Hadar Formation. Our work has identified three new fossiliferous stratigraphic units expanding our knowledge of the geological history of the region and providing context for our faunal and basin analysis.

Stratigraphy. Sedimentary exposures in the Mille-Logya area provide access to generally disconnected sections of up to $\sim 60 \mathrm{~m}$ in total thickness. Between these discontinuous exposures, extensive colluvial cover of volcanic, boulder- to cobble-sized material obscures most outcrop. Furthermore, a number of postdepositional faults divide the exposures into disconnected faultbounded blocks. Hence, our stratigraphic interpretations of relationships between sections are presently based on widespread marker beds, chemical groupings of interfingered basalts and tephras, nine new ${ }^{40} \mathrm{Ar} /{ }^{39} \mathrm{Ar}$ dates, and several magnetostratigraphic sections. These observations are sufficient to describe the overall stratigraphy, and to divide the sedimentary strata into three main fossiliferous intervals each exposed at one of the three main areas: Gafura, Seraitu, and Uraitele (Fig. 2). In this report, we designate these as informal stratigraphic units, with the aim of formalizing a regional lithostratigraphic terminology in future work, building on these presently informal terminologies.

The lowest stratigraphic unit, Gafura, (Fig. 2) begins with a sequence of thick, columnar-jointed basalt flows with intra-flow residual paleosols developed on the basalts. The Gafura sediments are poorly exposed, but occur along the southwestern flank of IkiIlu Ridge (Fig. 1), and are best represented by a section exposed at Sidiha Koma (section JGW15-1). The upper surface of the basalt flow at the base of this zone forms a broad low-lying surface, dissected by the Gafura River, extending into the base of the Daamé Valley. This sequence of basalts defines the GFB-I and GFB-II groups $(\mathrm{GFB}=$ Gafura Basalts); it underlies the main sedimentary sequence and is thus stratigraphically distinct from the overlying flows represented as the Afar Stratoid Series. Within the lowermost exposures of the Gafura Basalts, a normal to reverse magnetostratigraphic reversal is recorded (see Supplementary Table 5). Given the age constraints of overlying strata, this reversal must be equal to or older than the age of the base of the Kaena Chron $(3.127 \mathrm{Ma})^{33}$

The transition to overlying sediments of the Sidiha Koma area is marked by mudstones with ferruginized burrows interspersed with thin, poorly-sorted sands with a framework of basaltic lithic grains, occasionally containing abundant gastropods, and some bivalves. Near the top of Gafura sediments, additional basalt flows overlie the sediments locally, although these have not yet been attributed to one of the geochemically-defined groups (see Supplementary Figs. 1,2 and Supplementary Table 1). The fossiliferous sediments of Gafura underlie a widespread diatomaceous unit, the Iki-Ilu Diatomite, which can be mapped in regionally extensive exposures along the southwestern flank of Iki-Ilu Ridge, across its southern tip, and into the floor of the Seraitu Valley, making this a practical stratigraphic boundary. 


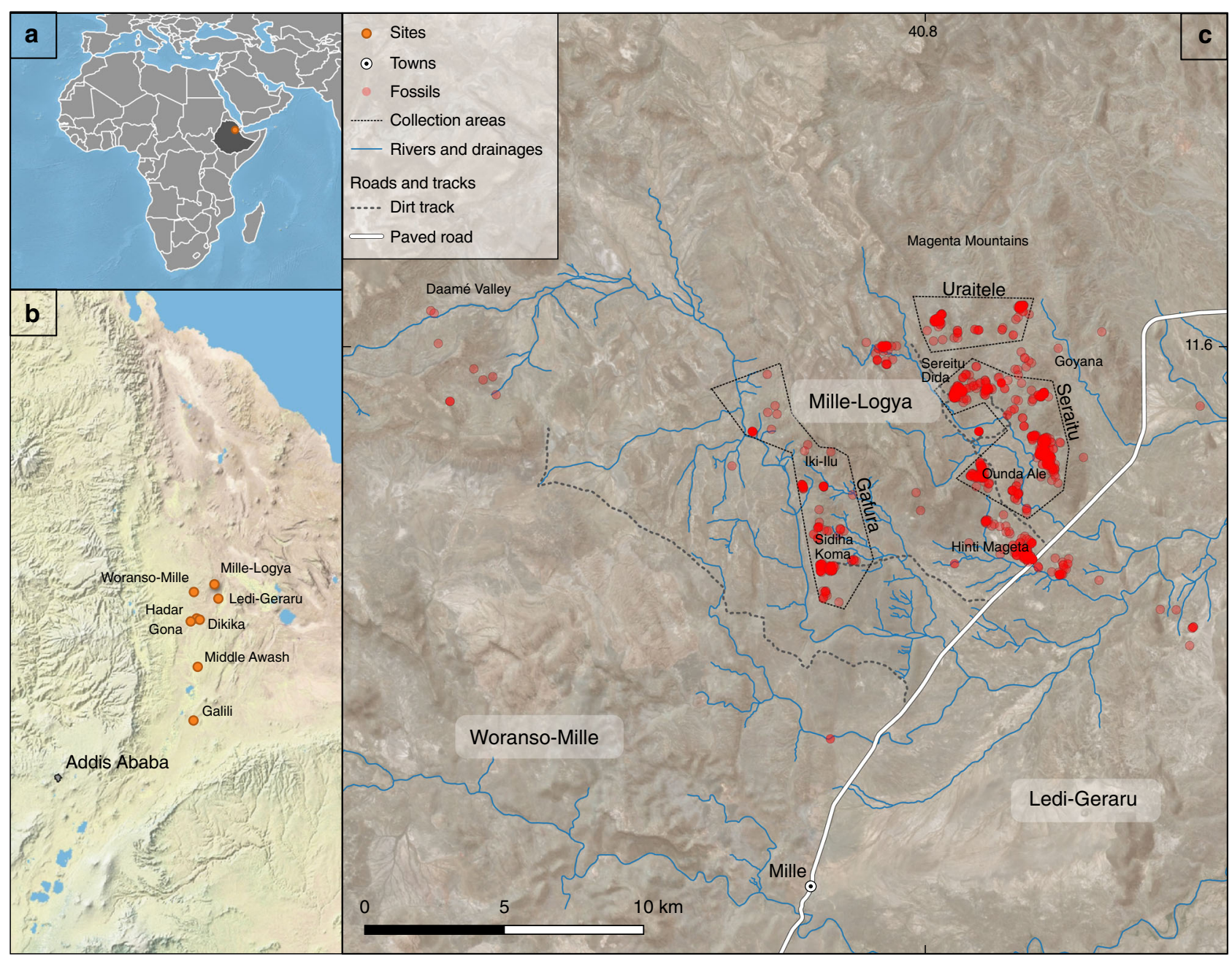

Fig. 1 Location of the Mille-Logya Project (MLP) area within the greater Afar sedimentary basin, Afar, Ethiopia. Panel a shows the location of MLP within Ethiopia; $\mathbf{b}$ the localtion of MLP relative to other major Plio-Pleistocene hominin sites in the Afar triangle; $\mathbf{c}$ the distribution of individual fossils and the three main collection zones (Gafura, Seraitu, and Uraitele) The maps in this figure were generated with the standard distribution of QGIS version 3.10.2.

The Hinti Mageta Tuff $(2.914 \pm 0.036 \mathrm{Ma}$; see Supplementary Figs. 3-5 and Supplementary Tables 4, 5), preserved within the Iki-Ilu Diatomite, provides an upper age limit to the Gafura sediments.

The middle stratigraphic unit is represented by the Seraitu lake beds, which often form bare, steep cliffs of largely mudstone outcrops representing lacustrine deposition. We use the base of the Iki-Ilu Diatomite as the lower boundary of this zone, although most sections cannot be mapped in continuity within a measured stratigraphic distance to the diatomite. The upper boundary of this zone may not be defined by a single widespread marker but can be locally taken as the stratigraphically lowest basalt flow with chemical composition characteristic of the UGB Group (UraiteleGarsele Dora Group), which may consist of several different flow units. The UGB is frequently accompanied by an overlying, distinctive and widespread air-fall tuff with well-preserved glass and small lapilli-sized pumices, the Goyana Tuff (see Supplementary Table 2). Thus, the presence of one or both of these markers provides a working stratigraphic definition.

The sediments of the Seraitu lake beds are predominantly laminated clays which often contain abundant ostracods, gastropods and some bivalves, as well as plant fragments and fish remains. Diatoms in the Iki-Ilu Diatomite are somewhat recrystallized but identifiable to the genus Aulacoseira ${ }^{34,35}$.
Tephras are also numerous in the lake beds but characteristically thin $(<30 \mathrm{~cm})$, often air-fall occurrences, in which the primary glass is altered. Despite this, abundant feldspar crystal populations are preserved, providing two of the ${ }^{40} \mathrm{Ar} /{ }^{39} \mathrm{Ar}$ dates reported here. Besides the Hinti Mageta Tuff at the base of the Seraitu lake beds, two tuffs within the lake sediments provide precise ages: MLP14/SR-6 at $2.576 \pm 0.008 \mathrm{Ma}$ and MLP14/GOY-2 at $2.485 \pm$ $0.018 \mathrm{Ma}$. In addition to the chronological information from these markers, two sections within the Seraitu lake beds zone record a magnetostratigraphic reversal which we interpret to be the Gauss/Matuyama, dated to $2.59 \mathrm{Ma}$ (Fig. 1; section JGW14-10 and in section JGW14-6; see Supplementary Figs. 6-8, Supplementary Table 5).

The third unit, Uraitele, includes limited sedimentary exposures in-between extensive and thick basalt flows of the UGB, GYB-I, and GYB-II groups, which outcrop in the Goyana and Uraitele areas. The sediments include some lenticular sandstones interpreted as fluvial channels, but are predominantly laminated mudstones with occasional gastropod and bivalve bearing sandstones formed on surfaces of the UGB basalt or within the mudstones. The upper boundary of the Uraitele zone is as yet undefined, as the section continues in a thick sequence of numerous basalt flows that extend into the ridges of the Magenta Mountains at the northern extent of the area (mapped as the Afar 


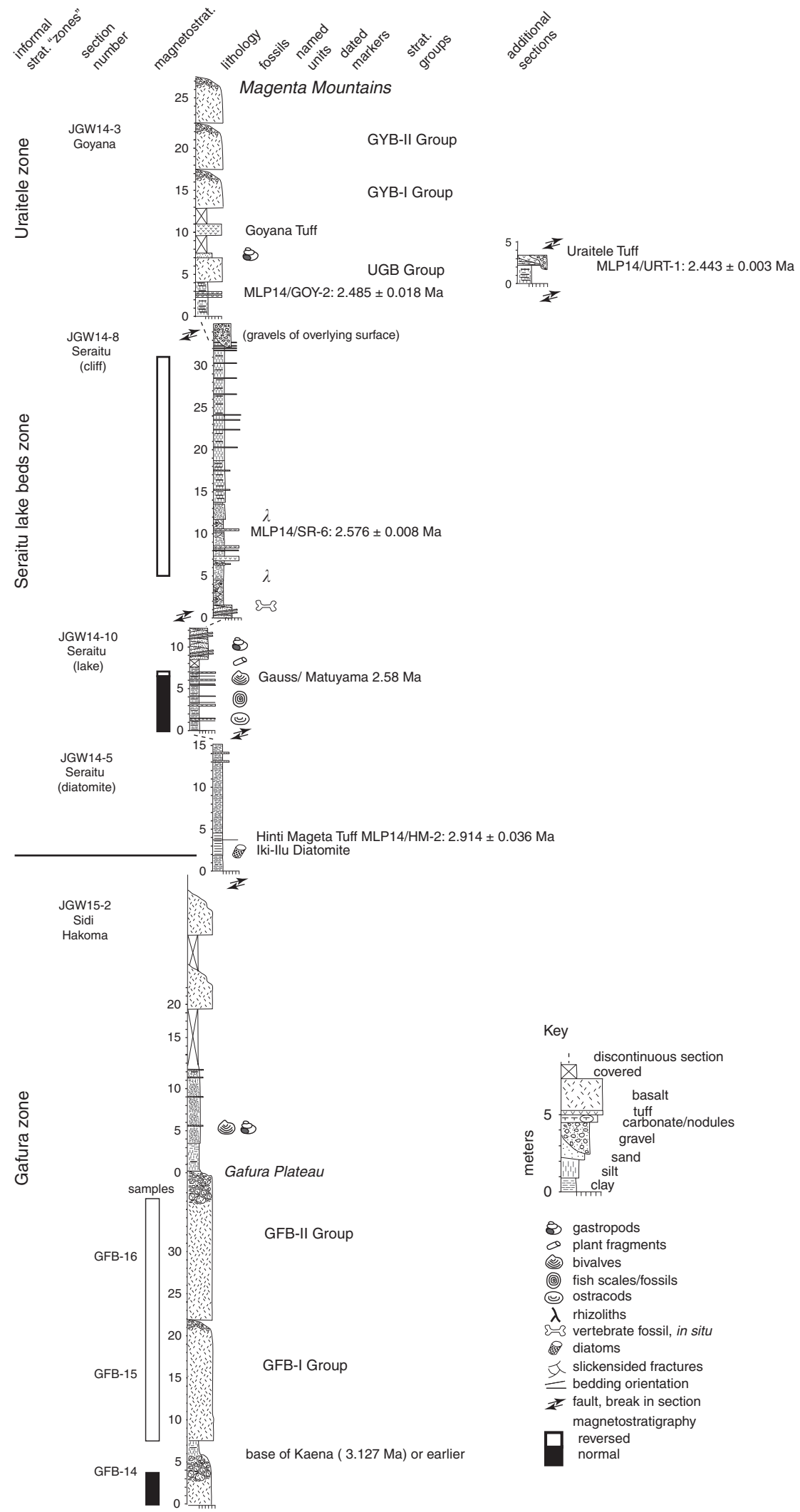

Fig. 2 Stratigraphic sections, sedimentary content volcanic markers, and relationships among the three fossiliferous zones (Gafura, Seraitu, and Uraitele) at the Mille-Logya Research area. 


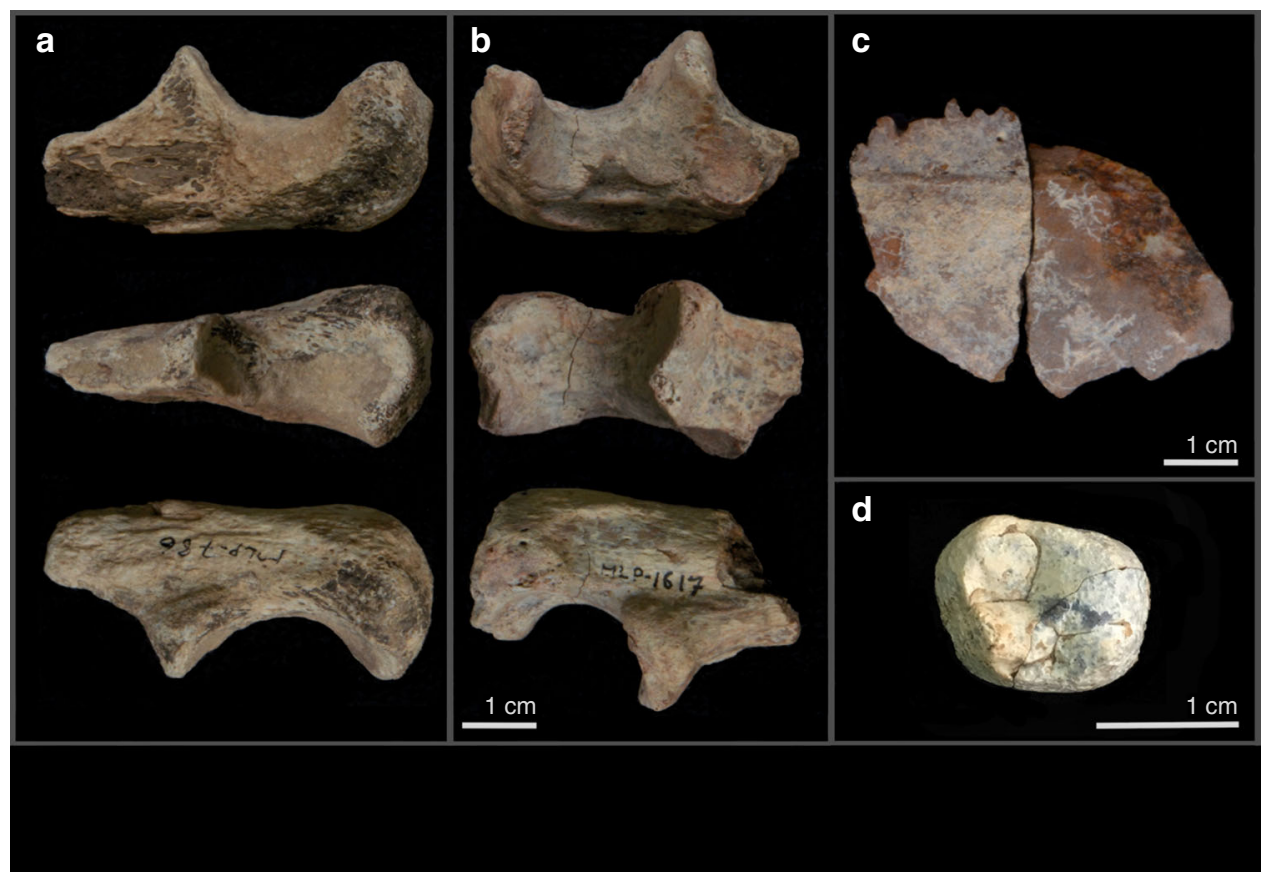

Fig. 3 Hominin remains from the MLP area. a, $\mathbf{b}$ are left and right proximal ulnae (MLP-786 \& MLP-1617, respectively from two different localities, thus not from the same individual); $\mathbf{c}=$ calvarium fragment (MLP-1469); $\mathbf{d}=$ a diagnostic and complete upper second molar crown (MLP-1549).

Stratoid Series ${ }^{20,21}$. The uppermost flows form two chemicallydistinct groups, termed the GYB-I and GYB-II groups (Supplementary Table 1).

As with the Gafura area, the sediments of the Uraitele area contain a number of reworked vitric tuffs generally lacking large feldspar populations, but having distinctive chemical composition with no known correlates from the Awash Valley (see Supplementary Table 2). One of these vitric tephras, the Uraitele Tuff, has also produced populations of feldspars suitable for dating, and represents the most precise age of those presently analyzed from the Mille-Logya area: $2.443 \pm 0.003 \mathrm{Ma}$.

Depositional history. Given the above stratigraphic sequence, we can make some important interpretations of the basin's history. Prior to $\sim 3 \mathrm{Ma}$, there is no evidence of an active depositional basin in the Mille-Logya region. Thus, during the period characteristic of most active lacustrine sedimentation at Hadar and Dikika $(\sim 3.6-3 \mathrm{Ma})^{14,15}$, the sequence of Gafura Basalts and residual paleosols at Mille-Logya suggests subaerial emplacement of basaltic lavas followed by periods of non-deposition and pedogenesis. The local onset of active subsidence and sedimentation is marked by early onset of shoreline and shallow lacustrine deposits overlying the uppermost GFB-II Group. The subsequent lacustrine sequence culminates in a deep, well-mixed lake represented by an Aulacoseira-dominated diatom facies within the Iki-Ilu Diatomite and invertebrate fossil rich mudstones preserved throughout the Seraitu lake beds zone. Few terrestrial indicators are present except occasional coarsergrained facies suggestive of shorelines or brief subaerial exposure, where occasional rhizoliths are preserved and vertebrate fossils are slightly more common. This lacustrine setting is persistent throughout the exposures and continues into the overlying Uraitele sediments, the lowermost of which are characterized by gastropod-bearing shoreline facies developed on the surface of basalt flows. Ultimately, the lacustrine phase ends with thin intervening sediments between basalt flows of the GYB Group, which have been associated with the fissural system of the axial rift $^{36}$.
Archaeology. Archaeological survey was conducted in conjunction with paleontological reconnaissance. Archaeological visibility is extremely low due to the combination of a thick colluvial cover, relatively few exposed sections and the fact that most of the sedimentary deposits are lacustrine in origin. Nevertheless, all of the fossiliferous localities and their surroundings were examined on multiple occasions. In general, lithic artifacts are infrequent and scattered at very low density. The only exception comes from Seraitu Dida where slopes on two adjacent ridges with sediments above the Uraitele Tuff have numerous handaxes and Levallois cores and flakes made on a fairly consistent coarse-grained but good quality volcanic material. While artifact densities were relatively high in this area, no concentrations suggested a source for this material that has temporal constraint. Nevertheless, we excavated three trenches at the crest of one of the ridges above the Uraitele Tuff. In one of these trenches, about one meter into a layer of gravel, we found a single Levallois flake. A maximum age is provided by the Uraitele Tuff $(2.443 \mathrm{Ma})$ but the minimum age remains unconstrained. Archeological exploration will continue.

Paleontology. The aforementioned stratigraphic setting provides a framework to interpret fossil data recovered from the three units. Fossil concentrations at Mille-Logya are sparse and relatively difficult to locate. Yet, after four field seasons, the fossil collection currently includes 2287 specimens, of which 1835 were collected while the rest were observed and documented on site (Table 1). Fossil collections at MLP followed a standardized protocol $^{37}$ in order to minimize collection bias. The identifiable specimens comprise 62 Cercopithecidae, 4 Hominidae, 33 Proboscidea, 10 Camelidae, 165 Suidae, 135 Hippopotamidae, 36 Giraffidae, 944 Bovidae, 218 Equidae, 21 Rhinocerotidae, 20 Carnivora, 17 birds, and some rodents, fishes, turtles, and crocodiles. Below is a summary description of the major faunal elements.

Hominidae: Hominins were recovered from four different localities and are represented by a left and right proximal ulnae (MLP-786 \& MLP-1617 respectively (Fig. 3a, b): 2.6-2.8 Ma; from two different localities, thus not from the same individual), a 


\section{Table 1 Distribution of vertebrate taxa across the MLP main} groups of exposures.

\begin{tabular}{|c|c|c|c|}
\hline & Gafura & Seraitu & Uraitele \\
\hline Deinotherium bozasi & - & $x$ & $x$ \\
\hline Elephas recki & $x$ & $x$ & $X$ \\
\hline Orycteropus sp. & - & $x$ & - \\
\hline Camelus grattardi & - & $X$ & - \\
\hline Aff. Hippopotamus protamphibius & $x$ & $x$ & $x$ \\
\hline Kolpochoerus limnetes & $x$ & $x$ & $x$ \\
\hline Kolpochoerus n.sp.? & - & $x$ & - \\
\hline Notochoerus euilus & $x$ & $x$ & $X$ \\
\hline Giraffa jumae/stillei & $x$ & $x$ & $x$ \\
\hline Giraffa pygmaea & - & - & $x$ \\
\hline Sivatherium maurusium & $x$ & $x$ & $x$ \\
\hline Aepyceros sp. & $x$ & $x$ & $X$ \\
\hline Connochaetes sp. & - & - & $X$ \\
\hline Damaliscus cf. ademassui & - & - & $x$ \\
\hline Damalborea sp. & - & $x$ & - \\
\hline Alcelaphini indet., very small & $x$ & $x$ & $x$ \\
\hline Gazella harmonae & $x$ & $x$ & $?$ \\
\hline Bovini indet. & $x$ & $x$ & $X$ \\
\hline Pelorovis cf. kaisensis & - & $x$ & - \\
\hline Kobus sigmoidalis & $?$ & $x$ & $X$ \\
\hline Kobus cf. oricornus & $x$ & $x$ & - \\
\hline Tragelaphus aff. lockwoodi & - & $?$ & $x$ \\
\hline Tragelaphus nakuae & $?$ & $x$ & $x$ \\
\hline Ceratotherium sp. & $x$ & $x$ & - \\
\hline Diceros sp. & - & $X$ & - \\
\hline Hipparionini sp. & $x$ & $x$ & $x$ \\
\hline Crocuta eturono & - & $?$ & $x$ \\
\hline cf. Dinofelis sp. & - & $x$ & $x$ \\
\hline Felidae indet., serval size & - & $x$ & - \\
\hline Cercopithecidae indet. & $x$ & $x$ & $x$ \\
\hline Theropithecus sp. & $x$ & $x$ & $X$ \\
\hline Homo sp. & - & - & $X$ \\
\hline Crocodylus sp. & $x$ & $X$ & $X$ \\
\hline Euthecodon sp. & - & $x$ & $x$ \\
\hline Chelonia & $x$ & $x$ & $x$ \\
\hline Anatidae indet. & - & - & $x$ \\
\hline Struthio sp. & $x$ & - & $x$ \\
\hline Siluriformes & - & $x$ & - \\
\hline
\end{tabular}

calvarium fragment (MLP-1469 (Fig. 3c): 2.6-2.8 Ma) and a diagnostic and complete upper second molar crown (MLP-1549 (Fig. 3d); 2.4-2.5 Ma). The molar, found in two pieces that refit cleanly, measures $14 \mathrm{~mm}$ and $12.5 \mathrm{~mm}$ buccolingually and mesiodistally, respectively, falling within the known range of $A$. afarensis as well as early Homo as represented by A.L. 666-1 from the younger horizons at Hadar dated at 2.33 Ma. The buccolingual and mesiodistal dimensions overlap with those of early Homo and are closest to the mean values (Fig. 4 a, b; Supplementary Fig. 10). The occlusal outline, which is dominated by the two mesial cusps, is rhomboidal with the longest axis running from the distolingual to mesiobuccal corners. The distobuccal corner is truncated. The tooth is moderately worn with no cuspal dentine exposure. The lingual wear flattens the protocone and hypocone and polishes the lingual margin leading to a rather homogenized region of the lingual half of the tooth. In contrast, the paracone and metacone are not as worn and the buccal margin is still sharp. The distal marginal ridge and distal fovea are quite perceptible, but the mesial marginal ridge is largely worn down leaving only a hint of the mesial fovea. In occlusal view, running buccal to the protocone and distal to the paracone is a large buccal groove that dominates other grooves and is positioned mesiobuccal to a lingual groove that is much smaller.

An asymmetric and rhomboidal occlusal outline of the upper second molar has been reported to characterize Homo erectus and $H$. habilis ${ }^{38,39}$ but is rare in $A$. afarensis ${ }^{36}$. The MLP M2 possesses these features but is buccolingually broad unlike Homo erectus. Based on size and average enamel thickness (Fig. 4 a, b; Supplementary Fig. 11) in addition to diagnostic occlusal features, we attribute it to Homo sp. With an age of $2.4-2.5 \mathrm{Ma}$, this molar represents one of the oldest specimens of this genus and expands the earliest Homo sample from the Afar, which currently includes only LD 350-1 from Ledi Geraru at 2.8 Ma and A.L. 666-1 from Hadar at 2.33 Ma.

The calvarium fragment is probably from the parietal; the bone is relatively thin and different from what is seen in middle Pleistocene specimens such as Bodo. MLP-1617 and MLP-786 are fragmentary proximal ulnae mainly preserving the olecranon and the trochlear notch. The two specimens differ in size and degree of preservation. While MLP-786 is larger, MLP-1617 is better preserved, especially its trochlear notch where the maximum mediolateral breadth, including the radial notch, is ca. $28 \mathrm{~mm}$. In MLP-786, most of the distal aspect of the trochlear notch including the radial notch is broken away. In both, various quadrants of the trochlear notch are mildly concave. Maximum radial notch dimensions are $13.4 \mathrm{~mm}$ anteroposteriorly and 9.4 $\mathrm{mm}$ superoinferiorly in MLP-1617. In both specimens, the olecranon process is moderately projected proximally and slightly more pronounced in MLP-786, as is seen in other hominins. The olecranon proximodistal height is $7.3 \mathrm{~mm}$ and $8.6 \mathrm{~mm}$ respectively and similar to that of A.L. 438-1 (A. afarensis). The trochlear keel is mild in MLP-1617 and not perceptible in MLP786. Posteriorly, MLP-1617 and MLP-786 measure $15.3 \mathrm{~mm}$ and $18.5 \mathrm{~mm}$, respectively at the middle of the trochlear notch and proximally they measure $20.8 \mathrm{~mm}$ and $23.6 \mathrm{~mm}$. The two ulnae can readily be assigned to Hominini based on the extent of the olecranon process and the orientation and extent of the trochlear and radial notches. Many features and dimensions discussed by Drapeau $^{40}$ to characterize most fossil hominins are preserved (mainly in MLP-1617) but further discrimination is not possible and these bones are therefore attributed to Hominini indet.

Cercopithecidae: cercopithecines, especially Theropithecus, are abundant though mostly represented by fragmentary teeth and extremities of postcranials. The MLP Theropithecus is characterized by diagnostic high crowned, bilophodont molars with deeply incised notches and clefts. Based on limited existing material, molar size appears larger than in representatives of $T$. oswaldi from the older members of the Hadar Formation. Some teeth displaying similar features are smaller; we interpret them as females of the same species. There are also several teeth that do not display these diagnostic Theropithecus features, which we assign to Cercopithecinae indet. pending recovery of more complete specimens.

Proboscidea: enamel fragments belonging to Deinotherium are frequently encountered, and a nearly complete skull was excavated at Uraitele. Dental elements and postcranials of Elephantidae are common as well, and some were collected; a complete M3 from Uraitele best matches Elephas recki shungurensis ${ }^{41}$ known from Omo Shungura Members C to F, but there are no clear boundaries between successive subspecies to allow more precise biochronological attribution.

Tubulidentata: a single mandibular fragment belongs to an aardvark (Orycteropus).

Camelidae: this family is extremely rare in the East African Plio-Pleistocene, and the discovery of ten specimens at MilleLogya is remarkable. One of them is the only partial skull known 

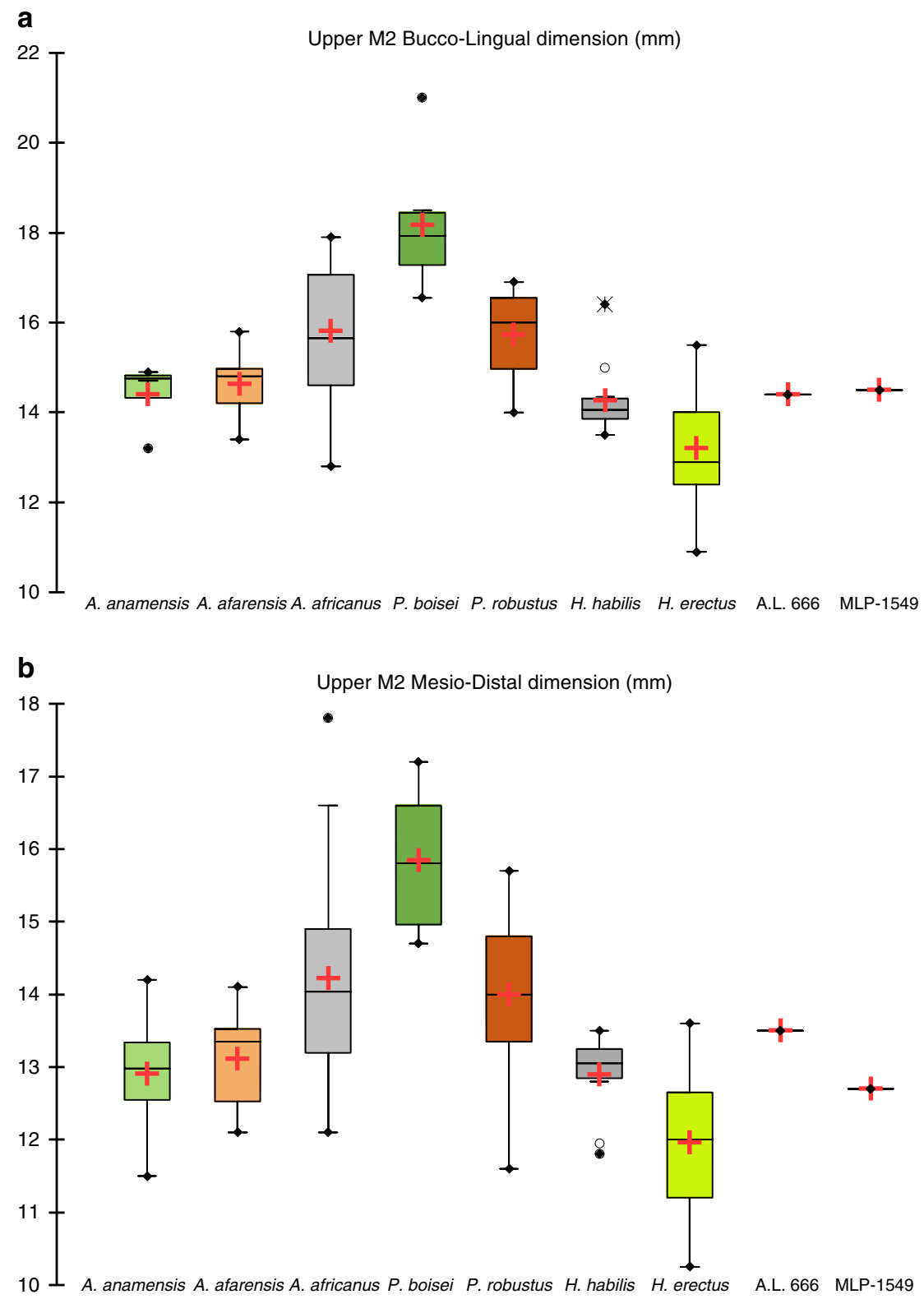

Fig. 4 Molar crown dimensions. Buccolingual and mesiodistal dimensions of MLP-1549 compared to values in Au. anamensis, Au. afarensis, Au. africanus, P. boisei, P. robustus, H. habilis, H. erectus \& A.L. 666-1(Homo sp. from Hadar dated to $2.33 \mathrm{Ma}$ ). a upper second molar bucco-lingual dimensions in mm; b upper second molar mesio-distal dimensions in $\mathrm{mm}$. Source data are provided as a Source Data file.

from this part of Africa to date and detailed analysis of this skull has been published elsewhere ${ }^{42}$.

Hippopotamidae: though remains of this group are common throughout the sequence, there is only one species; it has a hexaprotodont dentition, with a slightly smaller i2 than i1 and i3, thus resembling early forms of the 'aff. Hippopotamus protamphibius $^{\prime 43}$. It is clearly different from Hexaprotodon bruneti ${ }^{44}$, from the Hata Member of the Bouri Formation at ca. $2.5 \mathrm{Ma}$, which has a very large i3. Yet, formal identification must await the revision of the Turkana and Hadar material. No tetraprotodont dentition has been recovered from the MLP area.

Suidae: Notochoerus is the most common genus. Several complete third molars, mostly from the Gafura unit, are smaller than those of $N$. scotti from Omo C and later members, and match those of $N$. euilus from Omo B or the Hadar Formation. The morphology and mesiodistal length of their molars are similar to those in N. clarki, which coexists with N. scotti at Omo, but are broader and we attribute them to N. euilus. Kolpochoerus is less common and all specimens are of comparable size. Dimensions of the third molars, mostly from the Seraitu lake beds, are close to the upper end of the range for $K$. afarensis from the Hadar Formation, or to the lower end of the range for $K$. limnetes from Shungura D-E, and are closest to specimens from Shungura B and C. They are also somewhat larger than those of K. philippi ${ }^{45}$, from Matabaietu at ca. $2.5 \mathrm{Ma}$. There is no definite evidence of Nyanzachoerus, nor of Metridiochoerus.

Giraffidae: both Giraffa and Sivatherium are represented, but are rare. The relatively more common Giraffa is not particularly large, and a second, smaller species (G. cf. gracilis) is also present.

Bovidae: Bovids are by far the most common mammals, and almost half of the identifiable specimens, mostly represented by teeth, belong to Alcelaphini. They are followed in decreasing order of abundance by the Reduncini, Bovini, Aepycerotini, Antilopini, and Tragelaphini. Horn-cores are encountered 
relatively frequently, but are seldom associated with other cranial parts. An alcelaphin that resembles Damaliscus ademassui from Gamedah dated to ca. $2.5 \mathrm{Ma}^{46}$ and perhaps a primitive wildebeest (Connochaetes sp.) are present at Uraitele. We assign the most common alcelaphin to Damalborea, a genus that is present throughout the Hadar Formation ${ }^{47}$. Although variation at Hadar is great, the MLP form is distinctive in its short, twisted horn-cores with homonymous torsion. It could be an evolved form of D. grayi from the Denen Dora Member at Hadar. An unidentified, very small alcelaphin is reminiscent of the one that first appears in the Kada Hadar 2 submember ${ }^{47}$. There are at least two species of reduncins. The less common one is probably Kobus sigmoidalis, best known from the Turkana basin and recently reported from Ledi-Geraru ${ }^{11}$. The specific identity of the more common reduncin is not clear; it resembles $K$. oricornus from Omo Shungura $^{48}$, West Turkana, Koobi Fora ${ }^{49}$, and Hadar ${ }^{47}$. Surprisingly, this taxon is absent in the nearby Ledi-Geraru ${ }^{11}$. A Bovini horn-core from the middle part of the section is comparable to the type of Pelorovis kaisensis ${ }^{49}$, from Kaiso village in Uganda, ca. 2.5 Ma. Aepyceros is common but species identification is difficult due to incompleteness. One of the horncores is larger than those from the Kada Hadar Member. Gazella, the only antilopin so far recovered, is represented by several long and slender horn-cores resembling G. harmonae from the Kada Hadar Member at Hadar, and probably Omo Shungura Member $\mathrm{F}$ and Olduvai Bed I. Most tragelaphin horn-cores are from the younger part of the exposures and resemble Tragelaphus nakuae in their moderate torsion and in the presence of a low supraoccipital ridge of braincase. A very long horn-core is reminiscent of a specimen from Omo-160 in Shungura Member $C^{48}$. Overall, the tragelaphin material suggests an age of 2.6-2.3 Ma. A second and rare species from the middle part of the sequence is similar to T. gaudryi of which an ancestral form appears in Omo Shungura Member C.

Rhinocerotidae: Though rhinos are rare here, both the grazer Ceratotherium and the browser (or mixed-feeder) Diceros are encountered.

Equidae: Equids are fragmentary but quite common. We tentatively attribute all remains to a single species of hipparion. A complete set of upper incisors shows that the I3 is not reduced, and the lingual grooves are shallow, in contrast to what is seen in derived hipparions of the cornelianus group. A remarkable feature is the absence or poor development of the ectostylid on many lower teeth. A moderately worn and well-preserved set of molars shows no ectostylids at all. Postcranial dimensions are close to the lower end of the Hadar range $e^{50,51}$ where skulls show that at least two species are represented ${ }^{50,51}$.

Carnivora: Some postcranials potentially representing multiple taxa belong to Hyaenidae. Two metapodials and a tooth belong to a felid, cf. Dinofelis. In addition, a distal radius belongs to a servalsized felid.

Aves: A. Louchart (pers. com.) identified a large ostrich and a member of the Anatidae, perhaps Sarkidiornis melanotos or Plectropterus gambensis. Large ostriches have been mentioned from a number of Pleistocene Old World sites; they are likely attributable to Struthio asiaticus.

Crocodylidae: Crocodile teeth are widespread, and a few specimens represent Euthecodon.

Fishes: K. Stewart (pers. com.) identified bagrid and clariid fishes.

Biochronology and paleoenvironment. The Hadar Formation fauna, documented in the nearby sites of Hadar, Dikika, and Ledi-Geraru, has been widely studied and offers a very good reference for the new material from Mille-Logya. The Mille-Logya fauna points to a generally younger, late Pliocene age but shares a number of taxa with those from the Hadar Formation, where many have a wide chronological range. Of biochronological significance are the antelopes, Damalborea and Kobus cf. oricornus. Gazella harmonae is also shared with Hadar, although this species has wide chronological and geographic ranges. Another indicator of a similar age is the hexaprotodont hippopotamid, present in the middle part of the sequence at Mille-Logya. The suids also fall largely within the size range seen in the Hadar Formation, but most diagnostic specimens are encountered in the lower and middle parts of the sequence. It should be noted, however, that Kolpochoerus from the Seraitu lake beds is more consistent with the older absolute ages of this unit than with the younger ones. The absence of Nyanzachoerus suggests that the MLP assemblage postdates most of the fauna from Hadar. Although the above is generally true, there are differences within the Mille-Logya fauna indicating that sites in the southern portion of the research area are older than those in the north.

As in most African Pliocene sites, bovids are the most common group followed by equids and suids. Primates are fairly common but rare compared to those at Hadar and Dikika. One striking feature of the Mille-Logya fauna is the high prevalence of equids, particularly relative to suids. At Hadar and Dikika the reverse is consistently the case. While this is true when the whole MilleLogya assemblage is considered as a unit, looking at the different horizons reveals a different pattern. Gafura ( 2.9 to $2.8 \mathrm{Ma})$ contains fauna that is similar to that of Hadar where the proportion of bovids compared to suids and equids is not very high and also where suids are more common than equids. In contrast, the Seraitu lake beds ( 2.8 to $2.6 \mathrm{Ma})$ and Uraitele zone ( $\sim 2.5$ to $2.4 \mathrm{Ma}$ ) contain more bovids while equids overtake suids. This suggest that the older fauna in Gafura might have followed the migration of the Hadar Lake Basin northeast around $3 \mathrm{Ma}$, resulting in faunal similarities with Hadar. Relative faunal abundance however seems to have been altered in the younger horizons of the Seraitu lake beds and Uraitele (after $2.9 \mathrm{Ma}$ ), leading to a faunal assemblage indicative of more open conditions. This is supported by the overall abundance of bovids, particularly alcelaphins, and equids probably indicating an in situ faunal turnover.

We used all MLP specimens identifiable to genus to compute the Sørenson (also known as Dice) faunal dissimilarity index for each pairwise comparison among the faunal zones. The results indicate that Seraitu and Uraitele are more compositionally similar to one another (Sørenson $=0.31$ ) at the genus level than either of these zones is to Gafura (Gafura-Seraitu Sørenson $=0.4$, Gafura-Uraitele Sørenson =0.44). See Table 1 for faunal abundances in the three MLP zones. We further conducted a correspondence analysis on taxon abundances in order to compare the MLP faunal zones with assemblages from the Hadar Formation at Hadar and Dikika (Fig. 5). We restricted our analysis to seven bovid tribes (Aepycerotini, Alcelaphini, Antilopini, Bovini, Hippotragini, Reduncini, Tragelaphini), the suid genera Notochoerus and Kolpochoerus, and all Equidae identified only to family. These relatively broad taxonomic categories were chosen to reduce the influence of inter-observer variation in taxonomic identifications. The correspondence analysis (Fig. 5) demonstrates that the Gafura assemblage is distinct from the Seraitu and Uraitele assemblages, with Gafura showing a high abundance of Notochoerus, and the Seraitu and Uraitele assemblages showing a high abundance of Alcelaphini and Antilopini, which are openhabitat indicator taxa.

It is possible that some of the observed taxonomic differences between the collecting areas of successive ages are due to small sample size, but some have clear biochronological significance. 


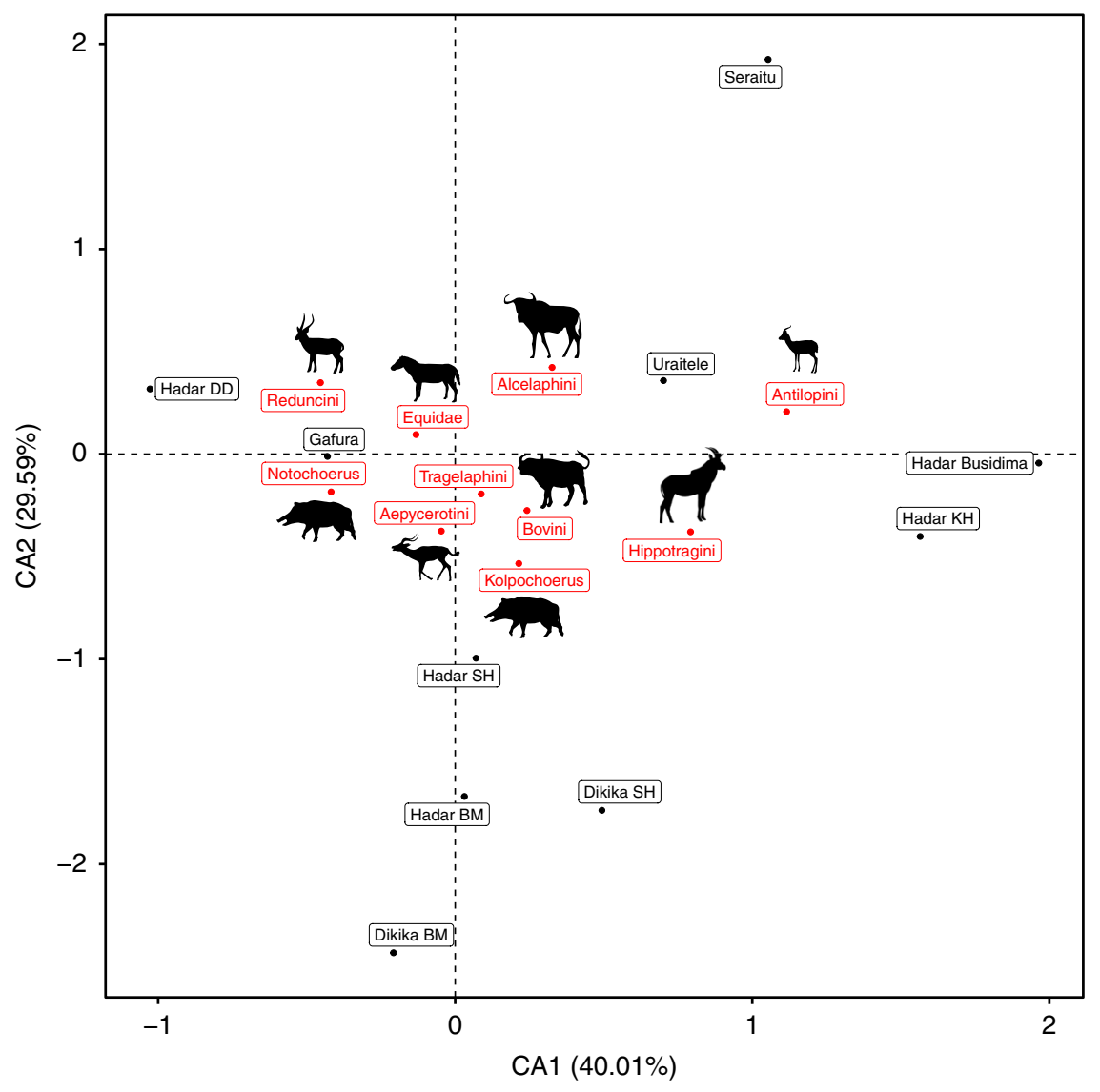

Fig. 5 Correspondence analysis on taxon abundances comparing the MLP faunal zones with assemblages from the Hadar Formation at Hadar and Dikika. Results demonstrate that the Gafura assemblage is distinct from the Seraitu and Uraitele assemblages, with Gafura showing a high abundance of Notochoerus, and the Seraitu and Uraitele assemblages showing a high abundance of Alcelaphini and Antilopini, which are open-habitat indicator taxa.

We interpret the presence of Damaliscus cf. ademassui, Connochaetes sp., and perhaps Kobus sigmoidalis, at Uraitele to suggest that the latter is younger than Gafura and Seraitu. In addition, it is not yet certain if the Tragelaphus from Gafura is a "typical" T. nakuae, and whether Damalborea survived into the Uraitele horizon.

In sum, the overall similarity of the Mille-Logya fauna, especially from the older Gafura sites, with that from the Hadar Formation is remarkable. Also, in spite of the apparent younger age, it contrasts with younger sites in the Middle and Lower Awash (Table 2). For instance, the bovid assemblage of Bouri Hata at ca. $2.5 \mathrm{Ma}^{52}$ includes a long list of bovid taxa for which there is no evidence at Mille-Logya: Beatragus, cf. Numidocapra, cf. Rabaticeras, Megalotragus, Hippotragus, Oryx, and Tragelaphus strepsiceros. The nearby Ledi-Geraru area contains sediments whose ages are very similar to those of Mille-Logya, but their faunal assemblage also looks different, containing Beatragus, Syncerus and Ugandax, but lacking Kobus oricornus, the most common reduncini at Mille-Logya.

In regards to paleoenvironments, tragelaphins are rare as are giraffes, while hipparions and reduncins are common. Alcelaphins are by far the most abundant bovids. The relative abundance of the otherwise rare Camelus is also noteworthy. On the whole, this assemblage points to an open savanna or grassland with little woody cover. This in conjunction with the presence of Homo at Mille-Logya may suggest that the earliest members of Homo were associated with more open environments than Australopithecus was. The in situ faunal change at MilleLogya may be linked to environmental and climatic factors that may have also caused Homo to emerge in or disperse to the region. Further field work and faunal analysis with better taxonomic resolution and use of additional proxies will help to better elucidate the paleoenvironmental and paleoecological conditions of this new site and its relevance to the understanding our origins.

Although the Afar Depression has contributed uniquely to our understanding of the biological and cultural evolution of hominins and faunal evolution more broadly over the past $6 \mathrm{Ma}$, paleontological data have been sparse in the region from the stratigraphic time interval $(2.9-2.4 \mathrm{Ma})$ represented by the Mille-Logya sediments. Our work shows the unique nature of the faunal assemblage and composition at the new site. The results suggest a northeast migration of the Hadar Basin and the creation of a new depocenter at Mille-Logya with continuity of the lake deposits and shoreline sediments that preserve a fauna similar to that from Hadar. Furthermore, we have identified three different fossiliferous units in this project area suggesting an in situ faunal change. Yet, relative to the Hadar Formation fauna, which is older than $3 \mathrm{Ma}$, Mille-Logya has a large proportion of alcelaphin bovids and equids, indicating that the area likely included more open habitats after $3 \mathrm{Ma}$. The absence of early Metridiochoerus, Menelikia and Australopithecus from Mille-Logya suggests that these habitats may not have been suitable for these taxa. The presence of Homo is instead suggestive of an adaptive shift in the transition between Australopithecus and Homo to settings with overall drier and more open conditions.

Looking forward, more research at MLP will allow better documentation of the geological setting and paleontological 
Table 2 Mille-Logya composite faunal list compared with those of the Hata Member of the Bouri Formation, and the Gurumaha-Lee Adoyta area.

\section{MLP}

Deinotherium bozasi

Elephas recki

Orycteropus sp.

Ceratotherium cf

mauritanicum

Diceros sp.

Hipparion s.l. sp.

Hexaprotodon sp

Kolpochoerus cf.

limnetes

-

Notochoerus euilus

Camelus grattardi

Sivatherium

maurusium

Giraffa cf.

camelopardalis

Giraffa cf. gracilis

Tragelaphus nakuae

Tragelaphus sp.?

Pelorovis sp.

Kobus sigmoidalis

-

Connochaetes sp.

Damaliscus cf.

ademassui

Damalborea sp.

Alcelaphini indet.

$-$

Aepyceros sp.

Gazella harmonae

-

cf. Dinofelis sp.

cf. Felis sp.

cf. Crocuta sp.

Homo indet.

Theropithecus sp.
Kobus cf. oricornus $2.5 \mathrm{Ma}^{52}$

2.8-2.5 $\mathrm{Ma}^{4,11}$

Deinotherium cf. bozasi Deinotherium bozasi

Elephas recki

shungurensis

Elephas recki

Orycteropus sp.

Ceratotherium sp.

Hipparion sp

Hexaprotodon bruneti Kolpochoerus limnetes

Metridiochoerus

andrewsi

Notochoerus sp.

Sivatherium sp.

Giraffa sp.

Tragelaphus nakuae

Tragelaphus

strepsiceros

Tragelaphus pricei

Ugandax coryndonae

Simatherium

shungurense

Kobus kob

Kobus sigmoidalis

Hippotragus gigas

cf. Oryx sp.

Beatragus whitei

Connochaetes gentryi

Damaliscus ademassui

\section{cf. Rabaticeras}

arambourgi

cf. Numidocapra

crassicornis

Megalotragus

kattwinkeli

Parmularius rugosus

Aepyceros

Gazella janenschi

Antidorcas sp.

Homotherium sp.

Genetta sp.

Aonyx aff. capensis

Australopithecus garhi

Theropithecus sp.
Hata Mb, Bouri Fm ca. Gurumaha-Lee Adoyta
Eurygnathohippus afarense Eurygnathohippus hasumense ippopotamidae sp. Kolpochoerus cf. philippi

Metridiochoerus andrewsi

Notochoerus sp.

Sivatherium maurusium

-

Tragelaphus gaudryi

Ugandax coryndonae

cf. Syncerus sp.

Menelikia Iyrocera

Kobus sigmoidalis

Beatragus sp. nov.

Connochaetes sp.

cf. Damaliscus sp.

cf. Damalborea sp.

Parmularius aff. pachyceras

Aepyceros sp.

cf. Gazella sp.

Parantidorcas latifrons

cf. Antilope sp.

cf. Dinofelis sp.

Homotherium sp.

Crocuta dietrichi

Homo sp.

Theropithecus darti
Bold taxa underline the most significant differences between MLP and any of the other two areas.

content of the poorly known post-Hadar-Dikika periods to better articulate the environmental setting of human evolution. For the first time, we now have a better understanding of the cause for local cessation of sedimentation in the Hadar-Dikika areas after approximately $2.9 \mathrm{Ma}$. The new data set will serve as the basis for within-site faunal comparison and for testing competing spatial and temporal faunal and environmental change hypotheses. The presence of hominin remains, including Homo associated with a diverse fauna presents a unique opportunity to address key questions that pertain to our genus and factors that led to its emergence and subsequent biological and cultural evolution.

\section{Methods}

Stratigraphy and sedimentology. Stratigraphic sections were measured with Jacob's staff and Brunton compass, and mapping done with hand-held GPS- and GIS-enabled devices. Samples were prepared for diatom analysis following Battarbee et al. ${ }^{53}$. In short, samples were placed in $30 \% \mathrm{H}_{2} \mathrm{O}_{2}$ to remove organic matter. Samples were rinsed with deionized water and dried on microscope cover slips. Cover slips were mounted to slides in Naphrax, a highly refractive media and analyzed under a Leica DM2500 light microscope at $\times 1000$ magnification.

Basalt and Tephra Geochemistry. Twenty-seven samples from Mile-Logya basalt samples were selected for major and trace element concentration determinations using a PANalytical $2404 \mathrm{X}$-ray fluorescence (XRF) vacuum spectrometer at Franklin and Marshall College, Lancaster, PA, USA following the techniques outlined in Mertzman ${ }^{54-56}$, as described in detail in Supplementary Note 1. In short, the analytical technique includes the determination of ferrous iron (FeO) by standard titration methods and total volatile content (LOI). We analyzed the chemical composition of volcanic glass from 25 tephra samples from the MilleLogya region using an electron microprobe (EMP). Major-element abundances were analyzed by wavelength-dispersive spectrometry on a JEOL 8900 Superprobe housed at the Smithsonian institution's Department of Mineral Sciences (2014 samples) or a JEOL 8900 Superprobe housed at the Carnegie Institution for Science's Geophysical Laboratory (2015 samples). For each tephra sample, 9-11 shards were analyzed. Both instruments were run with $12 \mathrm{kV}$, a $10 \mathrm{nA}$ beam current, and a $10 \mu \mathrm{m}$ spot size, conditions ideal for reducing alkali loss while obtaining reliable counts for elements such as Fe. We compared analyses of tephra from Mille-Logya with published analyses of tephras from throughout eastern Africa. We use the Borchardt coefficient ${ }^{52}$ to identify potential correlates based on glass chemistry. For chemically-similar tephras $(\mathrm{BC} \geq 0.85)$, we consider the degree of similarity, stratigraphic position and radiometric ages in evaluating tephra correlations.

${ }^{40} \mathbf{A r} /{ }^{39} \mathrm{Ar}$ dating. Four tuffs were dated by the ${ }^{40} \mathrm{Ar} /{ }^{39} \mathrm{Ar}$ method, selected for the presence of K-feldspar phenocrysts. The Hinti Mageta Tuff-2 (Sample MLP14/ HM-2) is a $2-3 \mathrm{~mm}$ thin, medium grained, crystal-lithic tuff that occurs within a several meter thick diatomite sequence, the Iki-elu Diatomite. Sample MLP14/SR-6 is one of several thin tephras within the Seraitu Lake section, and is a massive $\sim 20$ $\mathrm{cm}$ thick tuff with tabular feldspar grains up to $1 \mathrm{~mm}$ within an altered matrix. Sample MLP14/GOY-2 is a $\sim 10 \mathrm{~cm}$ thick pumiceous tuff with irregular upper and lower contacts and phenocrysts up to $1 \mathrm{~mm}$. The Uraitele Tuff (sample MLP14/ URT-1) is a $50 \mathrm{~cm}$ thick fine- to coarse-grained vitric tuff with bubble wall shards and fine pumice.

Mineral preparation was performed using standard techniques, involving gentle crushing, washing in distilled $\mathrm{H}_{2} \mathrm{O}$ and $5 \% \mathrm{HF}$, heavy liquid separations to isolate $\mathrm{K}$-feldspar, and hand-picking to minimize the presence of inclusions and any visible imperfections. Dated K-feldspars were in the $200-1000$ micron size range. K-feldspar concentrates were irradiated in the Cd-lined CLICIT position of the Oregon State University TRIGA reactor for six hours. Sanidine phenocrysts from the Alder Creek Rhyolite of California (orbitally referenced age $=1.1848 \pm 0.0006$ $\mathrm{Ma}^{53,56}$; were used as the neutron fluence monitor. Reactor-induced isotopic production ratios for these irradiations were: $\left({ }^{36} \mathrm{Ar} /{ }^{37} \mathrm{Ar}\right)_{\mathrm{Ca}}=2.65 \pm 0.02 \times 10^{-4}$, $\left({ }^{38} \mathrm{Ar} /{ }^{37} \mathrm{Ar}\right)_{\mathrm{Ca}}=1.96 \pm 0.08 \times 10^{-5},\left({ }^{39} \mathrm{Ar} /{ }^{37} \mathrm{Ar}\right)_{\mathrm{Ca}}=6.95 \pm 0.09 \times 10^{-4},\left({ }^{37} \mathrm{Ar} /\right.$ $\left.{ }^{39} \mathrm{Ar}\right) \mathrm{K}=2.24 \pm 0.16 \times 10^{-4},\left({ }^{38} \mathrm{Ar} /{ }^{39} \mathrm{Ar}\right) \mathrm{K}=1.220 \pm 0.003 \times 10^{-2},\left({ }^{40} \mathrm{Ar} /{ }^{39} \mathrm{Ar}\right)$ $\mathrm{K}=2.5 \pm 0.9 \times 10^{-4}$. Atmospheric ${ }^{40} \mathrm{Ar} /{ }^{36} \mathrm{Ar}=298.56 \pm 0.31$ and decay constants follow ${ }^{57}$.

Following a period of several weeks of radiological 'cooling' after irradiation, the feldspars were analyzed individually by the ${ }^{40} \mathrm{Ar} /{ }^{39} \mathrm{Ar}$ technique using singlecrystal incremental heating (SCIH). In the SCIH method, individual phenocrysts are incrementally heated in 4-7 steps (depending on grain size and gas yield) at progressively increasing power to fusion, to better examine the argon release patterns, drive off surficial argon in early steps, and maintain fairly consistent gas yields for better reproducibility. These detailed analyses were conducted on a $\mathrm{Nu}$ Instruments Noblesse noble-gas mass spectrometer, featuring a high-efficiency ionization source and simultaneous multi-isotope measurement using all ioncounting electron multiplier detection systems. A total of 300 SCIH steps on 91 phenocrysts from the four samples were analyzed (Table 1). 48 of these phenocrysts were rejected as candidates for complete step-heating analysis after one low-power steps, due to an obviously old xenocrystic ages or high $\mathrm{Ca} / \mathrm{K}$ content, whereas the remainder (43 grains) were carried to completion. All argon measurements were performed at the Berkeley Geochronology Center. Additional details of the ${ }^{40} \mathrm{Ar} /$ ${ }^{39} \mathrm{Ar}$ dating method as applied herein are provided in ref. ${ }^{58}$ and are described in greater detail in Supplementary Note 1.

Magnetostratigraphy. Paleomagnetic samples from the Gafura and Seraitu zones were collected in 2015. Sections were trenched for measurement, description, and paleomagnetic sampling. Paleomagnetic samples were drilled using a batterypowered $2.5 \mathrm{~cm}$-diameter diamond-coated bit cooled with air which was applied using a handpump. Orientation of the samples were measured using a geological compass and inclinometer - no dip correction was made for the bedding as the dip 
was below 5 degrees. After cutting the samples to standard size the measurement of the natural remanent magnetization (NRM) of the specimens and the progressive demagnetization was carried out in the laboratory of Paleomagnetism and Rock Magnetism at the University of Oxford (England). A pilot set of specimens were subjected to stepwise alternating-field (AF) demagnetization at applied peak fields of $0,5,10,15,20,25,30,35,40,50,60,70$, and $80 \mathrm{mT}$. Thermal demagnetization was done using the following temperature steps: $20,100,150,200,250,300,350$, $400,450,500,550,575$, and $600^{\circ} \mathrm{C}$. Most measurements and demagnetization steps were performed using a $2 \mathrm{G}$ Enterprises DC-SQUID cryogenic magnetometer with an in-line, triaxial, alternating field (AF) demagnetizer in a shielded room at the University of Oxford (United Kingdom). One batch of samples were thermally demagnetized following temperature steps $20,100,150,200,250,300,350,400$, $450,500,550$, and $600{ }^{\circ} \mathrm{C}$ at Fort Hoofddijk Paleomagnetic Laboratory of the Utrecht University (The Netherlands) on a 2G Enterprises DC SQUID cryogenic magnetometer. Thermal demagnetization was performed on an ASC thermal demagnetizer (residual field $<20 \mathrm{nT}$ ). Natural remanent magnetization (NRM) intensities were typically several orders of magnitude higher than the instrument sensitivity $\left(\sim 3 \times 10^{-12} \mathrm{Am}^{2}\right)$. The results of the demagnetization were interpreted to identify the Characteristic Remanent Magnetization (ChRM) directions using Paleomagnetism.org, an online open source tool for paleomagnetic data analysis ${ }^{59}$ ChRM directions were calculated with a minimum of four consecutive steps (See Supplementary Table 5). Paleomagnetism.org uses a set of techniques to statistically interpret the results ${ }^{60-64}$

For rock magnetic purposes Isothermal Remanent Magnetization (IRM) acquisition curve up to $1 \mathrm{~T}$ on five samples on a vibrating sample magnetometer (VSM, Micro- Mag Model 3900; Princeton Measurements).

Reporting summary. Further information on research design is available in the Nature Research Reporting Summary linked to this article.

\section{Data availability}

Data are available in Supplementary information. The source data underlying Fig. 4 and Supplementary Fig. 11 are provided as a Source Data file.

Received: 13 May 2019; Accepted: 7 April 2020;

Published online: 19 May 2020

\section{References}

1. Haile-Selassie, Y., Deino, A., Saylor, B., Umer, M. \& Latimer, B. Preliminary geology and paleontology of new hominid-bearing Pliocene localities in the central Afar region of Ethiopia. Anthropol. Sci. 115, 215-222 (2007).

2. Geraads, D., Melillo, S. \& Haile-Selassie, Y. Middle Pliocene Bovidae from Hominid-bearing sites in the Woranso-Mille area, Afar region, Ethiopia. Palaeonto. Afr. 44, 59-70 (2009).

3. Villmoare, B. et al. Early Homo at $2.8 \mathrm{Ma}$ from Ledi-Geraru, Afar, Ethiopia. Science 347, 1352-1355 (2015).

4. Bibi, F., Rowan, J. \& Reed, K. Late Pliocene Bovidae from Ledi-Geraru (Lower Awash Valley, Ethiopia) and their Implications for Afar Paleoecology. J. Vertebrate Paleontol. 37, e1337639 (2017).

5. Cohen, A. et al. The Hominin Sites and Paleolakes Drilling Project: inferring the environmental context of human evolution from eastern African rift lake deposits. Sci. Drill. 21, 1-16 (2016).

6. Campisano, C. J. et al. Hominin sites and Paleolakes Drilling Project: highresolution paleoclimate records from the east African rift system and their implications for understanding the environmental context of hominin evolution. PaleoAnthropology 207, 1-43 (2017).

7. Uno, K. T. et al. A Pleistocene palaeovegetation record from plant wax biomarkers from the Nachukui Formation, West Turkana, Kenya. Philos. Trans. R. Soc. B 371, 20150235 (2016).

8. Passey, B. H., Levin, N. E., Cerling, T. E., Brown, F. H., \& Eiler, J. M. Hightemperature environments of human evolution in East Africa based on bond ordering in paleosol carbonates. Proc. Natl Acad. Sci. USA 107, 11245-11249 (2010).

9. Sponheimer, M. et al. Isotopic evidence for Early Hominid Diets. Proc. Natl Acad. Sci. USA 110, 10513-10518 (2013).

10. Cerling, T. E. et al. Dietary changes of large herbivores in the Turkana Basin, Kenya from 4 to 1 Ma. Proc. Natl. Acad Sci. USA 112, 11467-11472 (2015).

11. DiMaggio, E. N. et al. Late Pliocene fossiliferous sedimentary record and the environmental context of early Homo from Afar, Ethiopia. Science 347, 1355-1359 (2015).

12. Semaw, S. The World's Oldest Stone Artefacts from Gona, Ethiopia: their implications for understanding stone technology and patterns of human evolution between 2.6-1.5 million years ago. J. Archaeological Sci. 27, 1197-1214 (2000).
13. Cerling, T. E. et al. Stable isotope-based diet reconstructions of Turkana Basin hominins. Proc. Natl Acad. Sci USA 110, 10501-10506 (2013).

14. Campisano, C. J. \& Feibel, C. S. Depositional environments and stratigraphic summary of the Pliocene Hadar Formation at Hadar, Afar Depression, Ethiopia. Geol. Soc. Am. Spec. Pap. 446, 179-201 (2008).

15. Wynn, J. G. et al. Stratigraphy, depositional environments and basin structure of the Hadar and Busidima Formations at Dikika, Ethiopia. Geol. Soc. Am. Spec. Pap. 446, 87-118 (2008).

16. Quade, J. \& Wynn, J. G. The Geology of Early Humans in the Horn of Africa (Geological Society of America, Boulder, 2008).

17. Wolfenden, E., Ebinger, C., Yirgu, G., Deino, A. \& Ayalew, D. Evolution of the northern Main Ethiopian rift: birth of a triple junction. Earth Planet Sci. Lett. 224, 213-228 (2004).

18. Wolfenden, E., Ebinger, C., Yirgu, G., Renne, P. R. \& Kelly, S. P. Evolution of a volcanic rifted margin: Southern Red Sea, Ethiopia. Geol. Soc. Am. Bull. 117, 846-864 (2005).

19. Hammond, J. O. S. et al. The nature of the crust beneath the Afar triple junction: evidence from receiver functions. Geochem. Geophys. Geosyst. https://doi.org/10.1029/2011GC003738 (2011).

20. Kazmin, V. Geological map of Ethiopia (Geological Survey of Ethiopia, Addis Ababa, 1973)

21. Tefera, M., Chernet, T. \& Haro, W. Geological Map of Ethiopia (1:2,000,000 Scale) and its Explanatory Note. (Ethiopian Institute of Geological Surveys, Addis Ababa, 1996).

22. Kalb, J. Adventures in the bone trade: the race to discover early human ancestors in Ethiopia's Afar depression (Copernicus Books, New York, 2001).

23. Taieb, M., Coppens, Y., Johanson, D. C. \& Kalb, J. Dépôts sédimentaires et faunes du Plio-Pléistocène de la basse vallée de l'Awash (Afar central, Ethiopie). C.R. Acad. Sci. D. 275, 819-882 (1972).

24. Taieb, M., Johanson, D. C., Coppens, Y. \& Aronson, J. L. Geological and palaeontological background of Hadar hominid site, Afar, Ethiopia. Nature 260, 289 (1976).

25. Taieb, M. \& Tiercelin, J. J. Sédimentation Pliocène et paléoenvironnements de rift: Exemple de la formation à Hominidés d'Hadar (Afar, Éthiopie). Bull. Soc. Géol. Fr. 7, 243-253 (1979).

26. Aronson, J. L. \& Taieb, M. In Hominid Sites: Their Geologic Settings (eds. Rapp, G. J. \& Vondra, C. F.) 165-195 (Westview Press, Boulder, 1981).

27. Tiercelin, J. J. In Sedimentation in the African Rifts (eds. Frostick, L. E., Renaut, R. W., Reid, I. \& Tiercelin J. J.) 221-240 (Geological Society of London Special Publication, London, 1986).

28. Kalb, J. E. et al. Geology and stratigraphy of Neogene deposits, Middle Awash Valley, Ethiopia. Nature 298, 17-25 (1982).

29. Kalb, J. E., Oswald, E. B., Mebrate, A., Tebedge, S. \& Jolly, C. J. Stratigraphy of the Awash Group, Middle Awash Valley, Afar, Ethiopia. Newsletters on Stratigraphy, 11, 95-127 (1982).

30. Kalb, J. E. Refined stratigraphy of the hominid-bearing Awash Group, Middle Awash Valley, Afar Depression, Ethiopia. Newsletters on Stratigraphy, 29, 21-62 (1993)

31. Deino, A. et al. ${ }^{40} \mathrm{Ar} /{ }^{39} \mathrm{Ar}$ dating, paleomagnetism, and tephrochemistry of Pliocene strata of the hominid-bearing Woranso-Mille area, west-central Afar Rift, Ethiopia. J. Hum. Evol. 58, 111-126 (2010).

32. DiMaggio, E. N. et al. Tephrostratigraphy and depositional environment of young $(<2.94 \mathrm{Ma})$ Hadar Formation deposits at Ledi-Geraru, Afar, Ethiopia. $J$. Afr. Earth Sci. 112, 234-250 (2015).

33. Lisiecki, L.E., Raymo, M.E. A Pliocene-Pleistocene stack of 57 globally distributed benthic $\delta^{18} \mathrm{O}$ records. Paleoceanography. https://doi.org/10.1029/ 2004PA001071 (2005)

34. Gasse, F. East African Diatoms Taxonomy, Ecological Distribution. 201 pp (Gerbruder Borntraeger, Berlin, 1986).

35. Mohan, J., Stone, J. R., \& Campisano, C. 2016. Three novel species of Bacillariophyta (Diatoms) Belonging to Aulacoseira and Lindavia from the Pliocene Hadar Formation, Afar Depression of Ethiopia, Phytotaxa 272, 235-247 (2016).

36. Barberi, F. \& Varet, J. Volcanism of Afar: Small-scale plate tectonics implications. Geol. Soc. Am. Bull. 88, 1251-1266 (1977).

37. Reed, D. et al. Digital data collection in paleoanthropology. Evolutionary Anthropology: Issues, News, and Reviews Wiley Online Library 24, 238-249 (2015).

38. Brown, B., Walker, A., Ward, C. V. \& Leakey, R. E. New Australopithecus boisei calvaria from East Lake Turkana, Kenya. Am. J. Phys. Anthropol. 91, 137-159 (1993).

39. Kimbel, W. H., Johanson, D. C. \& Rak, Y. Systematic assessment of a maxilla of Homo from Hadar, Ethiopia. Am. J. Phys. Anthropol. 103, 235-262 (1997).

40. Drapeau, M. S. Functional anatomy of the olecranon process in hominoids and Plio-Pleistocene hominins. Am. J. Phys. Anthropol. 124, 297-314 (2004).

41. Beden, M. Les éléphants (Loxodonta et Elephas) d'Afrique Orientale: systématique, phylogénie, intérêt biochronologique. Doctoral dissertation, (Univ. Poitiers, 1979). 
42. Geraads, D. et al. New Remains of Camelus grattardi (Mammalia, Camelidae) from the Plio-Pleistocene of Ethiopia and the Phylogeny of the Genus. J. Mamm. Evol. https://doi.org/10.1007/s10914-019-09489-2 (2019).

43. Weston, E. \& Boisserie, J. R. Hippopotamidae. in Cenozoic Mammals of Africa (eds. Werdelin, L. \& Sanders, W. J.) 853-862 (University of California Press, Berkeley, 2010).

44. Boisserie, J. R. \& White, T. D. A new species of Pliocene Hippopotamidae from the Middle Awash, Ethiopia. J. Vertebr. Paleontol. 24, 464-473 (2004).

45. Souron, A., Boisserie, J. R. \& White, T. D. A new species of the suid genus Kolpochoerus from Ethiopia. Acta Palaeontol. Pol. 60, 79-96 (2013).

46. Vrba, E. S. New fossils of Alcelaphini and Caprinae (Bovidae: Mammalia) from Awash, Ethiopia, and phylogenetic analysis of Alcelaphini. Palaeontol. Afr. 34, 127-198 (1997).

47. Geraads, D., Bobe, R. \& Reed, K. Pliocene Bovidae (Mammalia) from the Hadar Formation of Hadar and Ledi-Geraru, Lower Awash, Ethiopia. J. Vertebrate Paleontol. 32, 180-197 (2012).

48. Gentry, A. W. In Les faunes plio-pléistocènes de la basse vallée de l'Omo (Ethiopie). Cahiers de Paléontologie, Travaux de paléontologie est-africaine (eds. Coppens, Y. \& Howell, F. C.) 119-191.

49. Harris, J. M. In Koobi Fora Research Project. The fossil ungulates: Geology, Fossil artiodactyls and palaeoenvironments (ed. Harris, J. M.) Vol. 3, 139-320 (Clarendon Press, Oxford, 1991).

50. Eisenmann, V. In Les Faunes plio-pléistocènes de la basse vallée de l'Omo (Ethiopie). Cahiers de Paléontologie, Travaux de Paléontologie est-africaine (eds. Coppens, Y. \& Howell, F. C.) 13-55 (CNRS, Paris, 1985).

51. Bernor, R. L., Scott, R. L. \& Haile-Selassie, Y. A contribution to the evolutionary history of Ethiopian hipparionine horses (Mammalia, Equidae): morphometric evidence from the postcranial skeleton. Geodiversitas 27, 133-158 (2005).

52. De Heinzelin, J. et al. Environment and behavior of 2.5-million-year-old Bouri hominids. Science 284, 625-629 (1999).

53. Battarbee, R. W. et al. Tracking environmental change using lake sediments. Diatoms 3, 155-202 (2001)

54. Mertzman, S. A. K-Ar results from the southern Oregon-northern California Cascade range. Or. Geol. 62, 99-122 (2000).

55. Borchardt, G. A., Aruscavage, P. J. \& Millard, H. T. Correlation of the Bishop Ash, a Pleistocene marker bed, using instrumental neutron activation analysis. J. Sediment. Petrol. 42, 301-306 (1972).

56. Niespolo, E. M., Rutte, D., Deino, A. L. \& Renne, P. R. Intercalibration and age of the Alder Creek sanidine Ar-40/Ar-39 standard. Quat. Geochronol. 39 205-213 (2017).

57. Min, K. W., Mundil, R., Renne, P. R. \& Ludwig, K. R. A test for systematic errors in Ar-40/Ar-39 geochronology through comparison with $\mathrm{U} / \mathrm{Pb}$ analysis of a 1.1-Ga rhyolite. Geochim. Cosmochim. Acta 64, 73-98 (2000).

58. Deino, A. L. et al. Ar-40/Ar-39 dating, paleomagnetism, and tephrochemistry of Pliocene strata of the hominid-bearing Woranso-Mille area, west-central Afar Rift, Ethiopia. J. Hum. Evol. 58, 111-126 (2010).

59. Koymans, M. R., Langereis, C. G., Pastor-Galán, D. \& van Hinsbergen, D. J. J. Paleomagnetism.org: an online multi-platform open source environment for paleomagnetic data analysis. Comput. Geosci. https://doi.org/10.1016/j. cageo.2016.05.007 (2016).

60. Deenen, M. H. L., Langereis, C. G. C. G., van Hinsbergen, D. J. J. \& Biggin, A. J. Geomagnetic secular variation and the statistics of palaeomagnetic directions. Geophys. J. Int. 186, 509-520 (2011).

61. Fisher, R. Dispersion on a sphere. Proc. R. Soc. Lond. Ser. A. Math. Phys. Sci. 217, 295-305 (1953)

62. Kirschvink, J. The least-square line and plane and the analysis of paleomagnmetic data. Geophys. J. R. Astron. Soc. 62, 699-18 (1980).

63. Tauxe, L., Butler, R. F., Van der Voo, R., Banerjee, S. K. Essentials of Paleomagnetism. University of California Press (2010).
64. Zijderveld, J. D. A. A. C. Demagnetization of rocks: analysis of results, methods in palaeomagnetism. developments in solid Earth. Geophys. 3, 254-286 (2013).

\section{Acknowledgements}

We thank the Authority for Research and Conservation of Cultural Heritage and the Afar Regional State for permission to conduct field work in the Mille-Logya area. We also express our gratitude to the MLP field crew and the people of the Mille and Logya towns and environs for permission and logistical support. Funding to conduct field work was provided by Margaret and Will Hearst. J.G.W. was supported by an NSF IR/D program. M.J.S. was funded by the Netherlands Organisation for Scientific Research grants NWOALW 823.01.003 and is currently funded by Juan de la Cierva-Incorporación grant from Spanish Research Agency, MINCIU (reference IJCI-2017-34126). Part of M.J.S. fieldwork was funded by SNMAP.nl. We are grateful Fred Spoor for data on upper molars, to A. Louchart and K. Stewart for identifying the birds and fishes, respectively, and to T. Lehmann for confirming the identification of Orycteropus, and to Kelsi Hurdle and Shariwa Oke for help with formatting the references.

\section{Author contributions}

Z.A., J.W., D.G., D.R., W.A.B., S.P.M., A.D., M.A., and M.S. conducted fieldwork. Z.A., D.G., D. Reed., W.A.B., and RB described and analyzed fauna and hominins, J.W. studied geology and stratigraphy with contribution from $\mathrm{AD}$ (radiometric dating); M.A. (basalt geochemistry); M.S. (magnetostratigraphy); D. Roman (tephra geochemistry) and J.M. (diatoms). All authors contributed data and content used in the writing of the paper.

\section{Competing interests}

The authors declare no competing interests.

\section{Additional information}

Supplementary information is available for this paper at https://doi.org/10.1038/s41467020-16060-8.

Correspondence and requests for materials should be addressed to Z.A.

Peer review information Nature Communications thanks the anonymous reviewers for their contribution to the peer review of this work. Peer reviewer reports are available.

Reprints and permission information is available at http://www.nature.com/reprints

Publisher's note Springer Nature remains neutral with regard to jurisdictional claims in published maps and institutional affiliations.

Open Access This article is licensed under a Creative Commons Attribution 4.0 International License, which permits use, sharing, adaptation, distribution and reproduction in any medium or format, as long as you give appropriate credit to the original author(s) and the source, provide a link to the Creative Commons license, and indicate if changes were made. The images or other third party material in this article are included in the article's Creative Commons license, unless indicated otherwise in a credit line to the material. If material is not included in the article's Creative Commons license and your intended use is not permitted by statutory regulation or exceeds the permitted use, you will need to obtain permission directly from the copyright holder. To view a copy of this license, visit http://creativecommons.org/ licenses/by/4.0/.

(C) The Author(s) 2020 